LBNL-60613

\title{
The San Joaquin Valley Westside Perspective
}

\author{
Nigel W.T. Quinn PhD, P.E. \\ HydroEcological Engineering Advanced Decision Support \\ Earth Sciences Division, Berkeley National Laboratory \\ 1 Cyclotron Road, Berkeley, CA, 94720 \\ nwquinn@,lbl.gov
}

\section{J. Christopher Linneman, P.E.}

Summers Engineering Inc., 887 N Irwin St., P.O. Box 1122,

Hanford, CA 93232

linneman@summerseng.com

\author{
Kenneth K. Tanji, PhD \\ Professor Emeritus, \\ Department of Land, Air and Water Resources, \\ University of California - Davis, \\ Davis CA 95616 \\ kktanji@ucdavis.edu
}

March 27, 2006 


\section{ACKNOWLEDGEMENTS}

This paper was developed to represent the perspective of agriculture on the westside of the San Joaquin Valley in a one day symposium at the annual meeting of the Environmental Water Research Institute of the American Society of Civil Engineers in Omaha, Nebraska, May 22-24, 2006. The symposium was part of the World Environmental and Water Resources Congress and comprised of four papers, each looking at management of salinity and boron loads and compliance with TMDL's from different perspectives. Papers represented agriculture on the west and east sides of the Valley, the perspective of the regulators and of Basin agency planners. Bill Johnston organized and chaired the session at the symposium.

The author would like to acknowledge his coauthors Chris Linneman and Ken Tanji for their contributions and for making this tag-team approach to paper-writing an enjoyable experience. Thanks also to Lee Mao of the US Bureau of Reclamation for supporting the development of a west-side surface and groundwater simulation model (WESTSIM) which has provided the means of testing hydrologic assumptions that underpin the estimation of regional salt balance. Susan Hubbard kindly reviewed the draft report for the Earth Sciences Division. 


\title{
The San Joaquin Valley Westside Perspective
}

\author{
Nigel W.T. Quinn ${ }^{1}$, J. Christopher Linneman ${ }^{2}$ and Kenneth K. Tanji ${ }^{3}$ \\ ${ }^{1}$ Group Leader, HydroEcological Engineering Advanced Decision Support, Berkeley National \\ Laboratory, 1 Cyclotron Road Bld. 70A3317H, Berkeley, California 94720; nwquinn@,lbl.gov; \\ Member ASCE, EWRI. \\ ${ }^{2}$ Civil Engineer, Summers Engineering Inc., 887 N Irwin St., P.O. Box 1122, Hanford, CA 93232; \\ linneman@summerseng.com; Member ASCE, EWRI, USCID. \\ ${ }^{3}$ Professor Emeritus, Department of Land, Air and Water Resources, University of California - \\ Davis, Davis CA 95616; kktanji@ucdavis.edu; Life Member ASCE, Member EWRI.
}

\begin{abstract}
Salt management has been a challenge to westside farmers since the rapid expansion of irrigated agriculture in the 1900's. The soils in this area are naturally salt-affected having formed from marine sedimentary rocks rich in sea salts rendering the shallow groundwater, and drainage return flows discharging into the lower reaches of the San Joaquin River, saline. Salinity problems are affected by the imported water supply from Delta where the Sacramento and San Joaquin Rivers combine. Water quality objectives on salinity and boron have been in place for decades to protect beneficial uses of the river. However it was the seleniuminduced avian toxicity that occurred in the evaporation ponds of Kesterson Reservoir (the terminal reservoir of a planned but not completed San Joaquin Basin Master Drain) that changed public attitudes about agricultural drainage and initiated a steady stream of environmental legislation directed at reducing non-point source pollution of the River. Annual and monthly selenium load restrictions and salinity and boron Total Maximum Daily Loads (TMDLs) are the most recent of these policy initiatives. Failure by both State and Federal water agencies to construct a Master Drain facility serving mostly west-side irrigated agriculture has constrained these agencies to consider only In-Valley solutions to ongoing drainage problems. For the Westlands subarea, which has no surface irrigation drainage outlet to the San Joaquin River, innovative drainage reuse systems such as the Integrated Farm Drainage Management (IFDM) offer short- to medium-term solutions while more permanent remedies to salt disposal are being investigated. Real-time salinity management, which requires improved coordination of east-side reservoir releases and west-side drainage, offers some relief to Grasslands Basin farmers and wetland managers - allowing greater salinity loading to the River than under a strict TMDL. However, current regulation drives a policy that results in a moratorium on all drainage return flows to the San Joaquin River as will be explained in this paper. Seasonal wetlands have little choice but to drain in order to sustain waterfowl habitat. This paper summarizes the short and long term strategies available to westside agricultural and wetland entities and reviews implications of success and failure.
\end{abstract}




\section{Introduction}

The Westside of the San Joaquin River Basin comprises 0.49 million ha $(1.2 \mathrm{~m} \mathrm{ac})$ of mostly irrigated agricultural land located west of the San Joaquin River. The total salt load imported to the Westside of the Valley by surface water deliveries has been estimated to be approximately 1.7 million metric tons per year $(1.9 \mathrm{~m}$ tons per yr) (SJVDP, 1990). Approximately 0.45 million metric tons ( $0.5 \mathrm{~m}$ tons) of salts (primarily sodium sulfate) leave the Valley through the San Joaquin River each year. Of the total salt export, agricultural subsurface drainage discharged to the San Joaquin River accounts for about 34.6 million $\mathrm{m}^{3}$ per year $(28,000 \mathrm{ac}-\mathrm{ft}$ per $\mathrm{yr})$, and 110,000 metric tons (121,000 tons) of salt from an estimated 19,430 ha $(48,000 \mathrm{ac})$ of land with installed subsurface drains. In areas without installed subsurface tile drainage or outside the area of influence of surface and interceptor drains and without an adequate natural drainage outlet, salts accumulate in the groundwater aquifer and water tables rise over time compounding salt management problems.

The West-side of the San Joaquin River Basin can be broken into three distinct regions as defined by the San Joaquin Valley Drainage Program (SJVDP, 1990) which include the Westlands subarea - mostly comprised of Westlands Water District (WWD); the Grasslands subarea that includes the selenium affected areas draining directly to the San Joaquin River and about a similar sized area of seasonally managed wetlands; and the North-west subarea which is located north and outside the selenium affected area. The soils on the west-side are derived from sediments of the Coast Range marine sedimentary rocks and thus have elevated concentrations of soluble salts which are mobilized by infiltrating surface-applied water. Both the Grasslands agricultural and Westlands Subareas are within the arc of westside alluvial fans which originate in the shale beds of the coast range and produce runoff and eroded sediments elevated in selenium.

The California Regional Water Quality Control Board (Regional Board) is required under the Clean Water Act to develop Total Maximum Daily Load (TMDL) limits for receiving waters of the State, such as the San Joaquin River, that have been designated as impaired for water quality and placed on the $303 \mathrm{~d}$ list. Recognizing the natural origins of the salts and trace elements of concern, discharged to the River from the Westside sources, and the fact that during most years there is adequate assimilative capacity in the San Joaquin River to accommodate these pollutants, the Regional Board took an innovative approach when crafting the Salt and Boron TMDL. Previous studies by Quinn and Karkoski, 1998; Karkoski et al., 1995; and Quinn et al., 1997, using a detailed mass balance model of salt loading from Eastside and Westside sources between Lander Avenue and Vernalis on the San Joaquin River, demonstrated the ability to meet water quality objectives with relatively minor investments in drainage storage facilities. Hence, the Regional Board allowed for an exception from the strict numeric TMDL approach, with its conservative assumptions of low flow hydrology and high factors of safety, if Basin dischargers were to embrace the concept of "real-time 
water quality management" and invest in the necessary continuous monitoring and institutional management to implement the concept basin-wide. This option for sustainable salt management and other structural and non-structural responses to the published salt, boron and selenium TMDL's are described according to the subareas identified above.

This paper summarizes the short and long-term strategies available to westside agricultural and wetland entities, and reviews implications of success and failure. Other companion papers addressing water quality management in the San Joaquin River include Grober et al. (2006), Ward et al. (2006) and Ploss and Buck (2006).

\section{Westlands Subarea}

Westlands Water District (WWD) occupies most of the 0.26 million ha $(0.65$ million ac) Westlands subarea, in the southern half of the San Joaquin Valley (Fig. 2). The Coast Range, which is the origin of soils within the subarea, is composed predominantly of sandstones and shales of marine origin that contain salts, as well as trace elements such as selenium. The texture of the marine deposits depends on the relative position on the alluvial fan and ranges from coarse sand and gravel to fine silt and clay. The fine textured soils are characterized by low permeability and increased concentrations of water soluble solids, primarily salts and trace elements. One of the principal subsurface geological features of the subarea is the Corcoran Clay formation. Formed as a lake bed about 600,000 years ago, this clay layer ranges in thickness from 6 to $61 \mathrm{~m}$ (20 to $200 \mathrm{ft}$ ), underlies most of the subarea and dominates the subsurface hydrology. The Corcoran Clay divides the groundwater system into two major aquifers - a confined aquifer below and a semiconfined aquifer above.

The Westlands subarea receives a yearly average of $178 \mathrm{~mm}$ (7 in) of precipitation, most of which falls during the months of December through March. Approximately 60 different crops are grown in the Westlands subarea - the majority with irrigation. In the year 2000, cotton, tomatoes, wheat, and almonds comprised almost $64 \%$ of the 228,400 cropped ha $(564,200 \mathrm{ac})$ of the Westlands Water District (WWD) within the subarea. In WWD irrigation water sources include groundwater and Delta water through the conveyance system of the Central Valley Project (CVP). In the 1990's, approximately 40\% of all crop acreage was irrigated by surface systems (furrow and/or border irrigation), approximately $20 \%$ was irrigated by pressurized systems (sprinklers and/or drip irrigation), and approximately $40 \%$ was irrigated by a combination of surface and pressurized systems. Groundwater sources are more saline than surface water deliveries groundwater salinity of less than $1500 \mathrm{uS} / \mathrm{cm}$ is uncommon while surface water typically has an EC of less than $500 \mathrm{uS} / \mathrm{cm}$.

The Westlands subarea is contained in both the San Joaquin and Tulare drainage basins. A drainage divide has been shown to exist in the vicinity of the Kings River alluvial fan causing groundwater north of the divide to flow in a northeasterly direction toward the San Joaquin River. Fresno Slough lies in the Valley trough and drains north into the San Joaquin River at the Mendota Pool (Fig. 1). However the Westlands subarea has no direct surface drainage outlet to the River, nor any legal right to initiate such drainage. A Master Drain to the Delta was 
planned in the 1960's but never completed because of the State's inability to secure funds and the selenium toxicosis problems that developed at Kesterson Reservoir, a facility initially designed as an offstream regulatory reservoir for tile drainage.

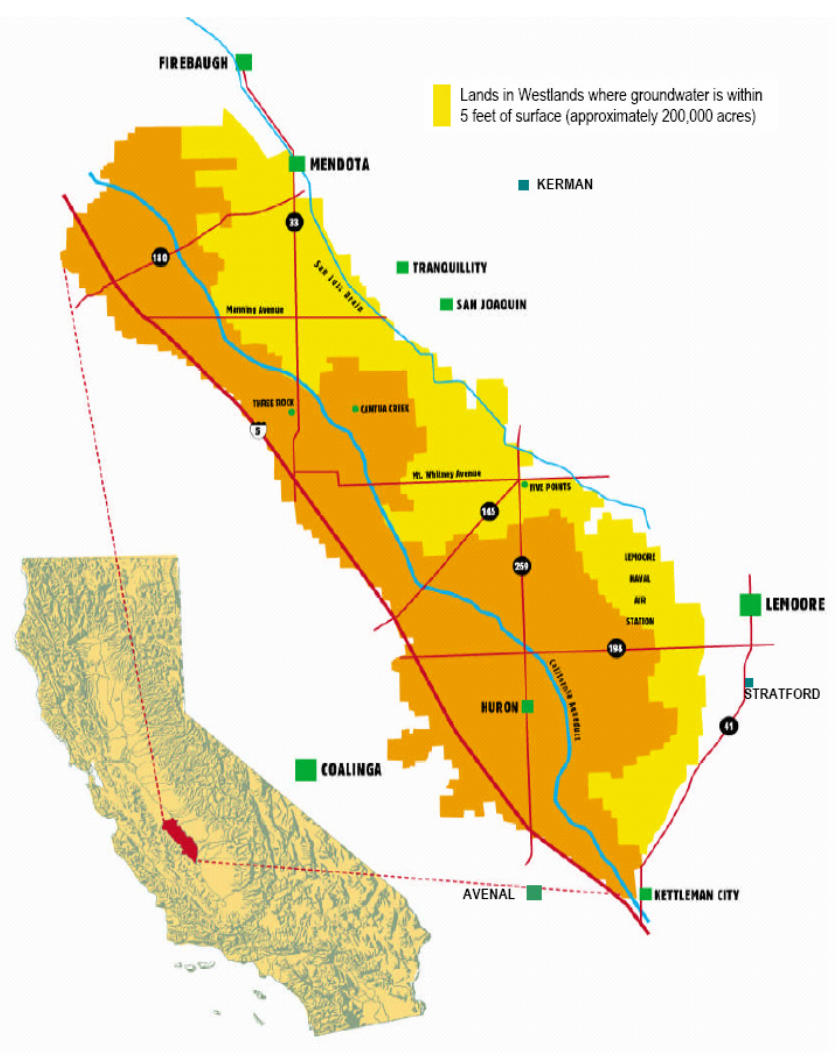

Figure 1. Map of Westlands Water District which dominates the Westland Subarea. Map shows areas of shallow groundwater. (Source: Westlands Water District, 2003).

The political fallout from Kesterson resulted in federal policy which required plugging of close to $2,100 \mathrm{ha}(5,200 \mathrm{ac})$ of land with tile drains in the north-west section of the WWD and regulation on all surface and subsurface drainage discharges to receiving waters if selenium concentrations exceeded $5 \mathrm{ppb}$. The end result has been to exacerbate the areal extent of shallow groundwater in the district, which has compounded problems associated with waterlogging and evapoconcentration of salts in the shallow aquifer and crop root zone. Groundwater levels are typically highest in April after pre-irrigation and lowest following the cropping season in October after crops have been harvested.

The Westlands subarea response to these drainage issues, that commanded national attention back in 1985, precede the salt, selenium and boron TMDL's. Since the subarea has no drainage discharge to the receiving waters of the State it is not directly affected by the TMDL. However these actions have an indirect impact on the hydrology of the Basin owing to regional groundwater flow from Westlands 
into the Grasslands subarea. Although Quinn and others, using two USGS models that overlay the boundary between the Westlands and Grasslands subareas (Belitz and Phillips., 1993 and Fio and Deverel, 1992) have estimated this migration at less than $5 \%$ of the deep percolation in any of the downslope, impacted water districts the implementation of water conservation, drainage recycling and other drainage reduction best management practices in the Westlands subarea is a benefit to drainage management and disposal in the Grasslands subarea.

Westlands Water District has been a leader in research and development of innovative source control. This district offers an irrigation guide providing realtime crop ET information including actual daily water use for the past 28 days and a 10-day forecast of crop water use. A Water Management Handbook (Westlands Water District, 1999) is also available for education and training of irrigators. The District poured considerable resources into cost-effective treatment technologies for removal of selenium from agricultural drainage. The first technologies assessed such as the Binnie process adapted conventional activated sludge reactor technology to reduce incoming selenate-selenium to less mobile reduced forms of the metalloid with subsequent unit processes to separate the selenium from the biological floc. These experiments at Adams Avenue Research Facility in WWD were followed by various physical-chemical processes such as the Harza iron-filing process and algal-bacterial pond system developed by Oswald at UC Berkeley within the Panoche Water District (PWD) of the Grasslands Agricultural subarea, a co-leader in drainwater treatment technologies. None of these technologies was able to consistently meet the selenium objectives of less than 5 ppb effluent water quality nor were they able to provide selenium load reduction at an affordable cost - at the time set at under $0.11 \$$ per $\mathrm{m}^{3}(140 / \mathrm{ac}-\mathrm{ft})$ of drainage treated. The District also experimented with Deep Well Injection but neither the underground formations nor the cost of disposal merited further development.

The single most promising source control technology that has come from these years of research by the District, within the Westlands subarea, has been Integrated Farm Drainage Management (IFDM). This technology was laid out conceptually in the final report of the San Joaquin Valley Drainage Program (SJVDP, 1990) and is a controlled reuse system whereby drainage is reused on progressively more salt tolerant crops with the final effluent discharged into a solar evaporator for later offsite disposal. Areas of each irrigated crop are carefully calculated and drainage carefully managed to ensure complete reuse at each step in the process. The IFDM system only works if all components are carefully tuned to keep root zone salts in check and to ensure adequate flushing of the crop roots. It achieves a salt balance by removing the salt from the productive land and storing it on farm.

Research conducted over the past 20 years in WWD and PWD has provided a laboratory for drainage management in subareas to the north of the WWD as they adapt to increasingly restrictive TMDL's that make it more difficult for farmers to achieve salt balance on their farmed lands. Soil salinization is a slow but progressive and inevitable process if salt balance is not achieved over the long term (Schoups et al., 2005). Then, the only responses to TMDL drainage restrictions or the lack of a drainage outlet are in-valley disposal options or land retirement. The WWD plans to retire about 45,000 hectares (100,000 acres) of agricultural land. 


\section{Grasslands Agricultural Subarea}

The Grasslands agricultural subarea, is located directly north of the Westlands subarea and mostly to the south of the Grasslands wetland subarea (Fig. 3). It is bounded by the Delta-Mendota Canal (DMC) to the north and California Aqueduct to the west and San Joaquin River on the east. Soils in the subarea are derived from low alluvial fans emanating from the Coast Range and are moderately to poorly drained. Some agricultural districts historically received a water supply from the natural flow of the San Joaquin River - others began receiving project water from the San Joaquin River in the 1940's under interim contracts. Contract negotiations for CVP water began in the late 1940's with USBR - long-term contracts were established in the mid-1950's allowing for delivery from the Delta-Mendota Canal. Development of the Friant Project also allowed for delivery of federally developed water in exchange for San Joaquin River natural flows. The subarea receives a yearly average of $229 \mathrm{~mm}$ (9 in) of precipitation, most of which falls during the months of November through March. 


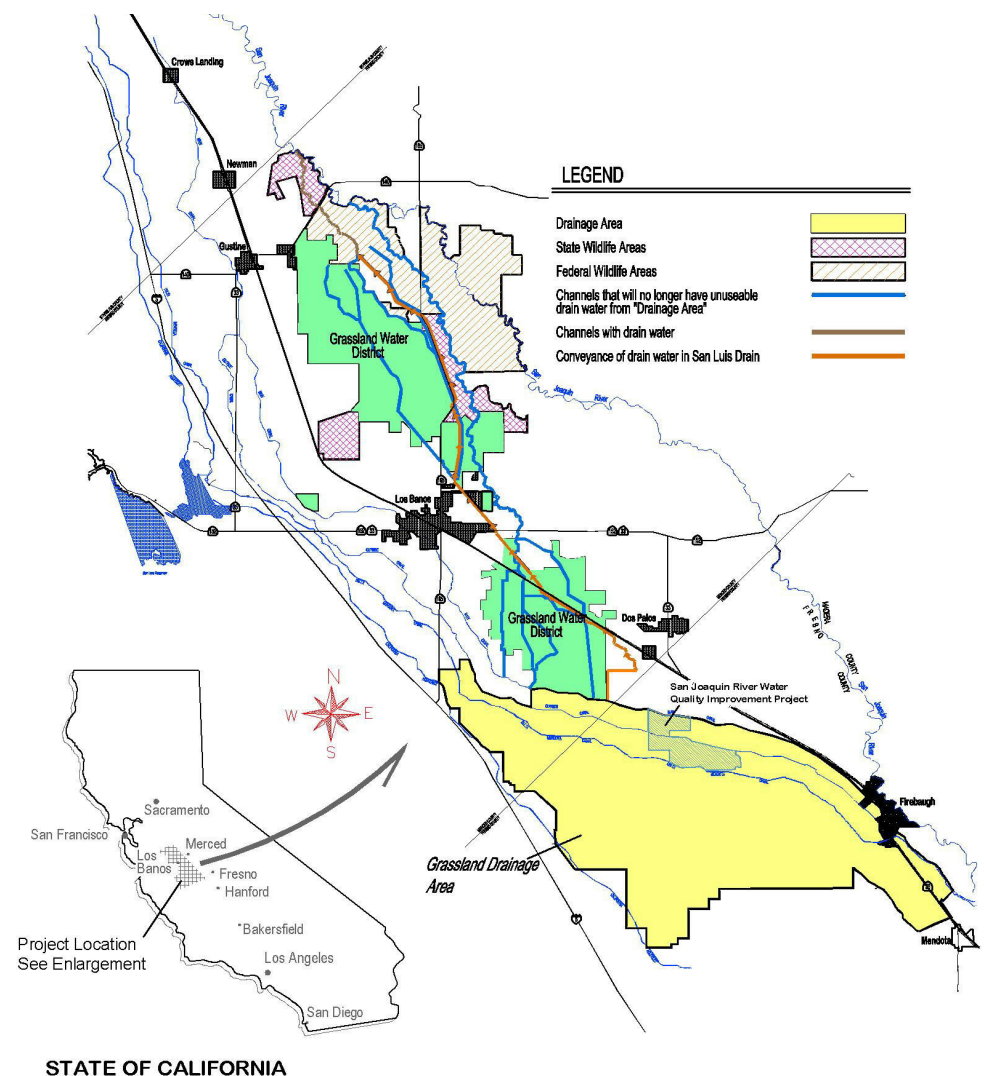

STATE OF CALIFORNIA

Grassland Drainage Area

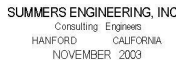

Figure 2. Map showing both the Grasslands Agricultural Area and the Grasslands Wetlands Area (commonly referred to as the Grasslands Ecological Area).

Most of the irrigated agricultural acreage in Grasslands agricultural subarea is in melons, cotton, alfalfa and tomatoes. The five major irrigation methods in the subarea (in order by highest to lowest acreage) are sprinkler (hand move) and graded furrow $(0.4 \mathrm{~km}(1 / 4 \mathrm{mi})$ length with siphon tube), drip (surface and subsurface), furrow $(0.4 \mathrm{~km}(1 / 4 \mathrm{mi})$ length with gated pipe), and sprinklers (hand move). Drainage water from the subarea was used and discharged historically through the Grassland Water District (GWD), and diverted into either Mud or Salt Sloughs in transit to the San Joaquin River. In 1996 the drainage water was rerouted through a newly constructed channel that bypassed the GWD, along $47 \mathrm{~km}$ (29 mi) of the former San Luis Drain into Mud Slough and the San Joaquin River (Fig. 3). The Grasslands Bypass Project had been conceived almost a decade earlier as a means of limiting waterfowl exposure to potentially toxic selenium in the agricultural drainage passing through almost $161 \mathrm{~km}(100 \mathrm{mi})$ of wetland channels and improving operational flexibility within GWD, which had to flush canals of selenium drainage water before making wetland deliveries.

When implemented in 1996 use of the federally owned San Luis Drain, by the project proponents, was made contingent on compliance with strict monthly and annual selenium load targets and the formation of a regional drainage management authority. The monthly and annual load targets for the 40,490 ha (100,000 ac) drainage service area (the majority of the Grasslands agricultural subarea) were 
established through a lengthy negotiated process between the water districts, State and Federal Resource Agencies, the Environmental Protection Agency and other stakeholder groups. Negotiated selenium load targets were set each month based on average monthly selenium loads from the project area - annual load targets were set at $3,000 \mathrm{~kg}$ per year $(6,600 \mathrm{lbs}$ per $\mathrm{yr})$, less than the sum of the monthly load targets. The annual selenium load targets were reduced by $5 \%$ per year in the last 3 years of the 5 year project and further reduced post-project with eventual compliance with Mud Slough selenium water quality objectives of $5 \mathrm{ppb}$ slated for 2009 (Fig. 3).

Incremental drainage incentive fees of up to $\$ 250,000$ were to be levied for exceedence of either annual or mean monthly selenium load targets. In order to meet load targets and avoid financial penalties local farmers and water districts implemented the most aggressive source control and drainage management program ever conceived in the Central Valley coupled with a subarea-wide drainage flow and water quality monitoring program. In the first few months of the project continuous flow meters were installed at each of the main discharge points. Daily selenium samples were taken at water district outlets and in the San Luis Drain to develop a database of load contributions from various sources. Telemetered water quality sensors were installed allowing real-time access to each district's contribution to overall drainage flow. Water meters were retrofitted on drainage sumps and discharge points within each district in order to estimate the drainage flow contribution from each sump and the mass contribution to each District's selenium load. With this knowledge individual water districts were able to develop their own internal load targets based on correlations between selenium loads and monthly flows at individual sumps.

Water districts also mandated drainage management policies throughout the subarea such as non acceptance of tailwater return flows into the drain. The water districts worked with individual farmers to design and construct tailwater return systems so as to blend tailwater returns with surface water deliveries. Some drainage tile systems were also retrofitted with in-line control weirs to allow selenium drainage discharges to be regulated. In the case of tile systems that discharged to sumps - sump pump control sensors were raised to allow discharge only when water tables in the field rose to within $1.5 \mathrm{~m}(5 \mathrm{ft})$ of the ground surface. 

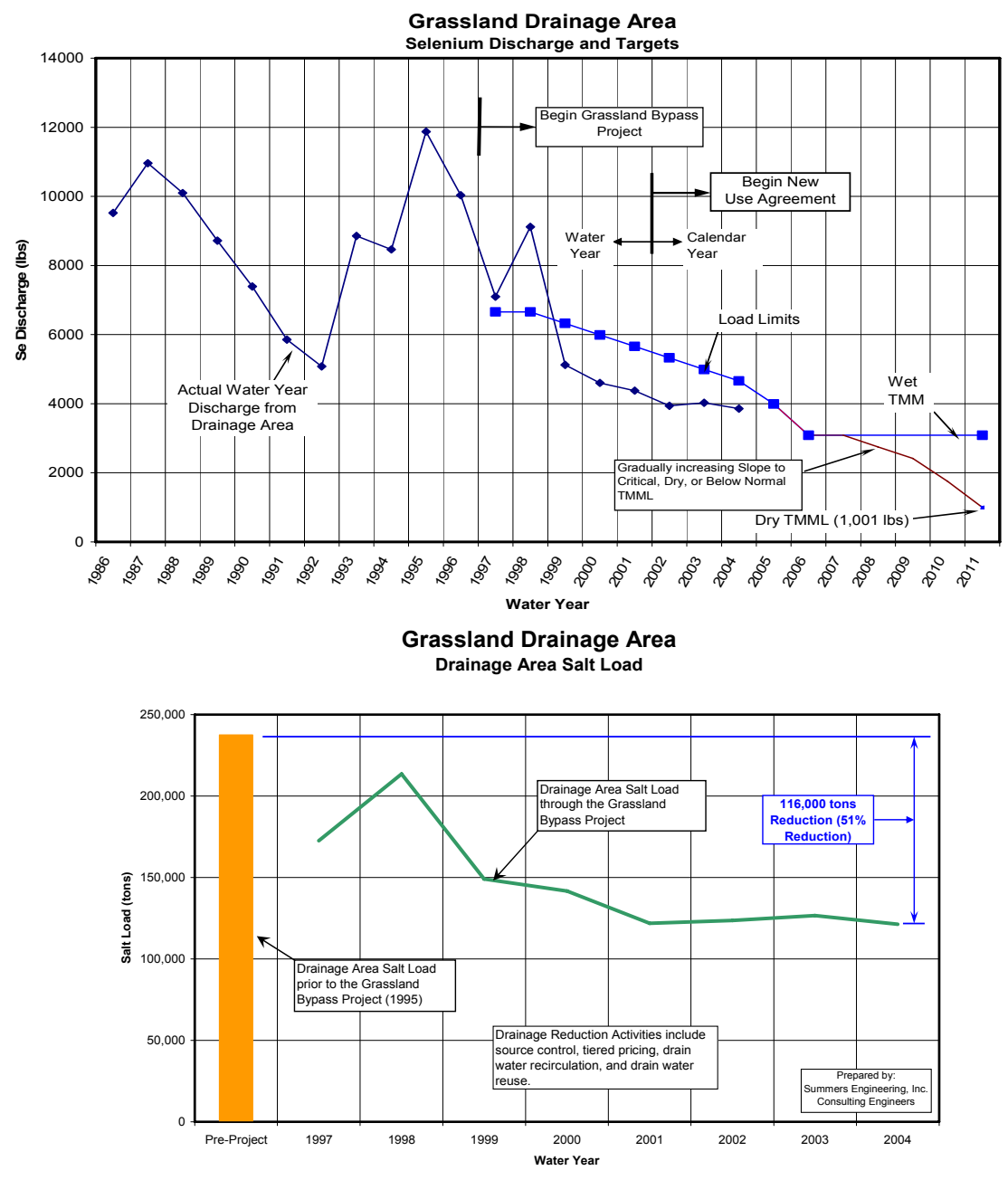

Figure 3. Comparison of pre-project and post-project selenium and salt loads showing the success of the project and demonstrating the potential for real-time water quality management of the San Joaquin River Basin.

Similarly, shallow groundwater levels were assessed through the construction of field water level indicators, color coded floating risers that protruded from shallow monitoring wells observable from the roadside that revealed the red colored band of the riser when water levels were sufficiently high to affect crop yields from rise of salts into crop root zone. This clever device, publicly visible, provided indirect peer pressure to those landowners whose water management practices allowed excessive deep percolation after irrigation and was very effective at improving on-farm drainage source-control practices. In the case of drains that discharged directly to open ditches - some main lines were severed and weir control structures installed at the outlet to help store more drainage water beneath each field prior to discharge to the District's drainage system.

District policy of tiered water pricing for water deliveries had been in place for several years prior to the Grasslands Bypass Project and in some cases was modified to encourage drainage reduction. This policy generally provides water 
equivalent to average evapotranspiration requirements at a base rate and sells water above this basic need at an increased cost. Likewise water district policies of implementing separate tiered pricing for pre-irrigation addressed the propensity for lower on-farm irrigation efficiencies at the beginning of the irrigation season. Districts have installed regional recirculation systems, where subsurface drain water was collected and pumped back into the regional irrigation system. Irrigation water quality was closely monitored, and TDS levels within district canals were not allowed to exceed $800 \mathrm{mg} / \mathrm{L}$. Other drainage management activities include a drainage reuse project, where subsurface drain water is used to irrigation salt tolerant crops, and research into drainage treatment using reverse osmosis.

The success with which the Grasslands Area farmers have reduced selenium discharges from the project area. Figure 3 compares cumulative plots of selenium loads for the first eight years of the project (1997-2003) and the two previous water years (1995 and 1996). Although selenium drainage targets were exceeded in January, February and April in the first year of the project this was not unexpected owing to the atypical distribution of rainfall. The selenium load targets were based on mean selenium loads over a nine year period 1985 - 1994, none of which produced record floods in January followed by unusually dry months in March and April. Despite the adversities of weather and market forces, average reductions of $30-40 \%$ from the base selenium loading objectives were achieved. A unique feature of the Grasslands Bypass project was the spirit of co-operation being shown between water districts in this novel program. Rather than attempt to legally define each water district's share of the collective selenium discharge target load, the participants have chosen to work as one unit in meeting goals allowing participating water districts to strive to implement best management practices at their own pace. The advances made in the past 9 years were an intensive learning experience for water districts within the subarea and individual growers alike as they sought ways to sustain agriculture while complying with water quality objectives defined by the Grassland Bypass Project Technical Oversight Committee to improve water quality conditions in the San Joaquin River.

Despite the success of the Grasslands Bypass Project and indications of vindication for the Regional Board that their experiment with a non-traditional TMDL approach, that recognized available assimilative capacity for salt, selenium and boron in the San Joaquin River, was a feasible approach for the San Joaquin Basin - a more conservative long-term plan was adopted. This plan calls for the elimination of all subsurface drainage discharge from agriculture in the Grassland Drainage Area to the San Joaquin River by 2009 and a program, endorsed by the multi-stakeholder San Joaquin River Water Quality Management Group, that includes source control measures, drainage water reuse on salt tolerant plants, and drainage treatment to cope with salt, selenium and boron contaminant loads. Although a suboptimal plan, which would foreclose continued exploitation of the San Joaquin River as a legitimate drainage outlet as allowable to the limit of assimilative capacity, it recognizes the difficulties in implementing the Regional Board's version of real-time water quality management in the San Joaquin River.

Even allowing for a supply water relaxation of up to $50 \%$, which recognizes the salinity levels in supply water from the CVP, and excuses half of the salt load of 
imported Delta Water, the TMDL has insufficient flexibility to be seen as a panacea for future drainage management. The requirement that any real-time water quality management system be practiced "Basin-wide" places the onus of proof on other entities outside the immediate control and influence of water districts in the Grasslands agricultural subarea. While real-time management is appealing to farmers in Grassland subarea, it is not practical unless the selenium loads can be removed from agricultural drainage. Regardless of the salt load requirements, the Grassland Bypass Project cannot meet selenium waste discharge objectives of 5 ppb in Mud Slough. A bypass around Mud Slough has been discussed, is expensive and is unlikely to receive environmental endorsement.

\section{Grasslands Wetland Subarea}

The Grasslands Wetland subarea comprises the Grassland Ecological Area (GEA) a mix of private, state and federal wetlands which together constitute the largest contiguous wetland complex in the western United States. The subarea is just over 40,490 ha $(100,000 \mathrm{ac})$ in aerial extent and is located immediately north of the Grasslands agricultural subarea (Fig. 2). The soils of the Grasslands wetland subarea are generally high in silt and alluvial clay especially in the bottomlands adjacent to the San Joaquin River. These are lands that flooded regularly before their development and the onset of irrigated agriculture and are poorly drained suitable for low quality grazing and the establishment of managed wetlands.

Seasonal wetlands in the Grasslands Wetland subarea are flooded in the fall and drawn-down in the spring to provide habitat for migratory waterfowl, shorebirds, and other wetland-dependent species. Due to alterations in natural hydrology, these wetlands are flooded with CVP water supplies delivered through GWD canals. In the spring, during the months of March-April, seasonal wetlands are drawn-down to mimic the natural dry cycle of a seasonal wetland. Wetland drawdowns are timed to make seed and invertebrate resources available during peak waterfowl and shorebird migrations and to correspond with optimal germination conditions (primarily soil temperature) to grow naturally occurring moist-soil plants. The seeds of moist-soil plants are recognized as a critical waterfowl food source, providing essential nutrients and energy for wintering and migrating birds (Fredrickson and Taylor 1982). Optimal timing of wetland flood-up and release has been determined by trial and error for different species of moist-soil plants and for different environmental conditions, although guidelines for these practices are poorly documented.

The seasonal wetland drainage discharge to the San Joaquin River contains varying amounts of total dissolved solids (TDS) and boron, which is largely evapoconcentrated supply water combined with salts and organic compounds derived from overwintering waterfowl and decomposing plant material. Increased water supply allocations under the Central Valley Project Improvement Act (CVPIA) - environmental legislation that resulted in a large transfer of water from irrigated agriculture to the environment - has created greater incentives for the coordination of seasonal wetland drainage with the assimilative capacity of the San Joaquin River (Grober et al.,1995; Quinn and Hanna, 2004; Quinn et al., 2004;Karkoski et al., 1995; Quinn et al., 1997; Quinn and Karkoski, 1998). Unlike 
the agricultural water districts to the south in the Grasslands Agricultural subarea these wetlands have to be drained annually to sustain soil fertility and prevent a build-up of toxic salts in the shallow root zone. Certain native moist-soil plants such as swamp timothy, watergrass and smartweed have high value as sources of protein for over-wintering waterfowl and are highly sensitive to salt, germination temperatures and soil moisture status - any one of these factors can severely compromise the value of the wetland habitat to migratory birds.

Salinity and boron TMDL's were promulgated to include discharges from seasonal wetlands in the San Joaquin Basin much to the disappointment of the wetland community which has hitherto had an uphill battle securing firm water supplies to ensure the vitality and ecological health of the resource. Selenium TMDL's are not relevant to this area because water deliveries cannot be made to these wetlands if selenium concentrations are in excess of $2 \mathrm{ppb}$. Selenate selenium assimilation within biota and adsorption of the more reduced selenite and selenide forms to sediments tend to reduce selenium levels in wetland drainage to below detection. An EPA selenium water quality objective for receiving waters of 5 ppb was established based on toxicity to fish and wildlife species.

Real-time water quality management as applied to seasonal wetlands would alter the timing of wetland drawdown to better match periods of assimilative capacity in the San Joaquin River. In most water years this would most likely require delayed drawdown until mid April, when the Vernalis Adaptive Management Program (VAMP) requires prescribed reservoir releases to aid salmon out-migration. Flow in the River can more than double during this period producing an excess of assimilative capacity for both salt and boron - sufficient to accommodate drainage loading from seasonally managed wetlands.

Although attractive conceptually, the response of moist-soil plants and of migratory waterfowl and shorebirds to an altered draw-down regime has not been assessed over the long-term. This assessment will identify potential impacts to seed germination rates, waterbird foraging rates, habitat availability, and species diversity and abundance. It is possible that early, experimental drawdown may make food sources available to wildlife without negatively affecting wetland vegetation community and plant species diversity - hence benefiting both wildlife and the health of the San Joaquin River.

\section{North-West Subarea}

The North-West subarea lies between Interstate I-5 and the San Joaquin River and is bounded by the cities of Tracy to the north and Gustine to the south. The soil types vary from clay, clay loam to loam and are moderately to well drained. The water table gradient running easterly toward the San Joaquin River is relatively steep providing good natural drainage. The northwestern subarea is dominated by five agricultural water districts - Del Puerto Water District, West Stanislaus Irrigation District, Patterson Irrigation District, Banta Carbona Irrigation District and the Central California Irrigation District (CCID) (Fig. 4). With the exception of Del Puerto Water District, all of these have riparian diversion rights to San Joaquin River water. CCID is an exchange contractor with pre-1914 water rights, a 
large portion of which were exchanged with the US Bureau of Reclamation for firm water deliveries from the Delta - which allowed Reclamation to build Friant Dam and divert the San Joaquin to agricultural areas in Madera and Kern counties in the eastside of the valley. Water supplies to these districts are therefore a blend of high quality surface water from the DMC, poorer quality water from riparian diversions of the San Joaquin River and during drought years, pumpage from district-owned and private groundwater wells which still have poorer water quality.

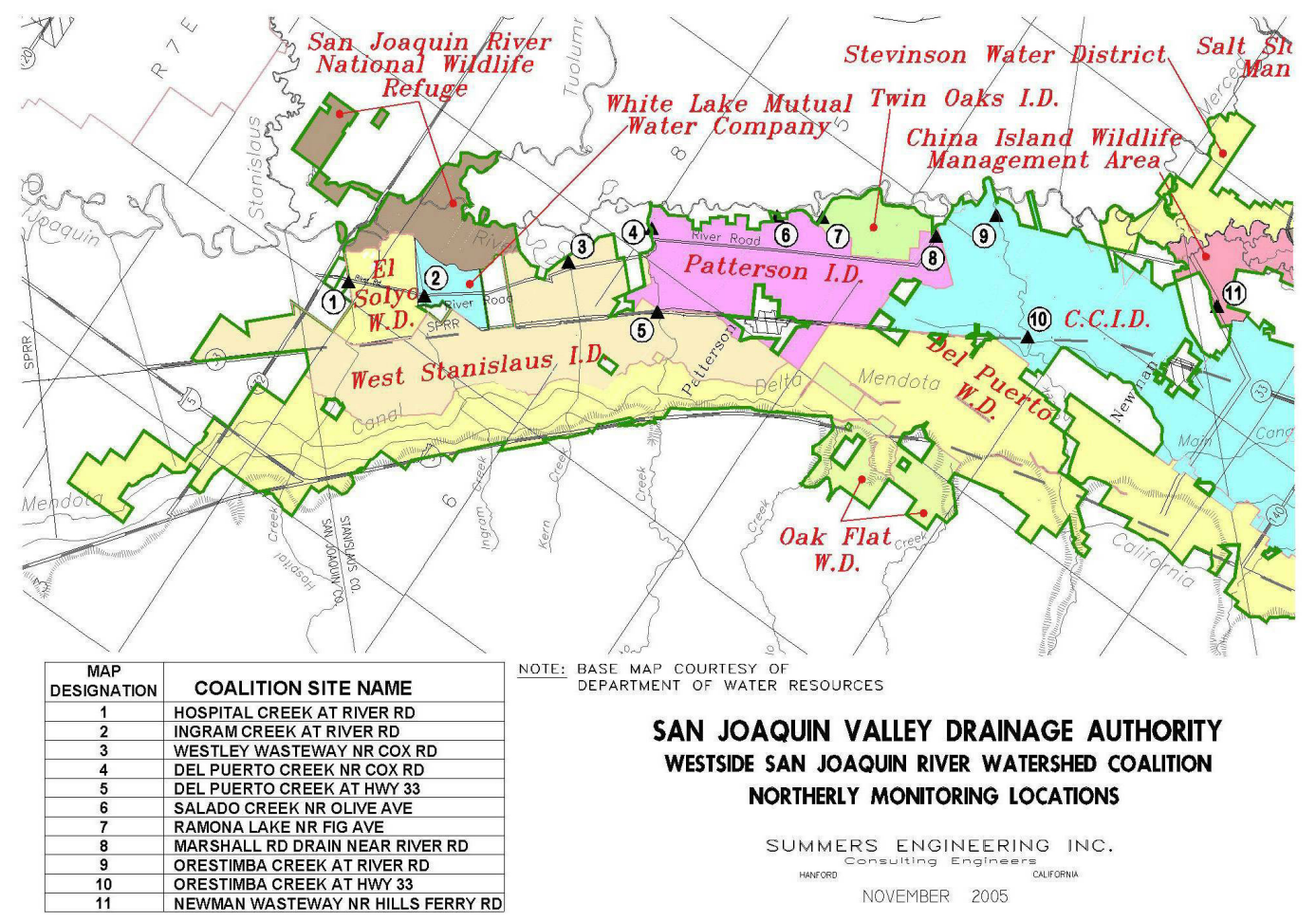

Figure 4. North-West Subarea showing agricultural districts and the Westside San Joaquin River Watershed Coalition monitoring stations.

The North-West subarea receives a yearly average of $262 \mathrm{~mm}(10.3 \mathrm{in})$ of precipitation, most of which falls during the months of November through March. Total acreage and irrigable area have remained constant for a long time in this subarea with the majority of agricultural acreage used to produce almonds, apricots, dry beans, green beans, melons, peas, walnuts, wheat, and processing tomatoes. The five major irrigation methods in this subarea (in order by highest to lowest acreage) are furrow (gated pipe), border (gated pipe), sprinkler, and micro/drip. There is little need for tile drainage in this subarea and a series of westside ephemeral streams - Orestimba Creek, Solado Creek, Del Puerto Creek, Hospital and Ingram Creeks convey much of the surface drainage to the San Joaquin River (Fig. 4).

Salinity and boron TMDL's also concern the water districts in the North-West subarea. Although there is lower average concentration of salt and boron in drainage return flow, the concentrations will still need to be managed to meet the 
TMDL regulations. This area may be able to take advantage of the real-time component of the TMDL. The response in the northwest side water districts has been to accelerate the construction of drainage reservoirs.

\section{TMDL's and Resource Sustainability}

The Regional Board attempted to develop a realistic TMDL strategy for the Westside of the San Joaquin Basin that recognized the difficulty of non-point source drainage pollutant reduction in an arid environment. The TMDL approach with its concept of choosing an extreme low flow hydrology (lowest $10^{\text {th }}$ percentile of flow) is more pertinent to humid zone agriculture where the annual range of watershed or basin runoff does not vary as widely. The incentive program adopted by the Board was designed to encourage adoption of a real-time water quality management approach basin-wide. Through recent regulatory efforts such as the Irrigated Lands Waiver program and incentive programs that encourage investment in continuous drainage flow and water quality monitoring - real-time management of water quality in the San Joaquin River may yet be achievable.

\section{References}

Belitz, K., Phillips, S.P., et al. (1993). Numerical simulation of ground-water flow in the central part of the western San Joaquin Valley, California. U.S. Geological Survey water-supply paper no. 2396. Washington, D.C., U.S. Geological Survey.

Fio, J.L., and Deverel, S.J. (1991). Ground-water flow and solute movement to drain laterals, western San Joaquin Valley, California, 2, Quantitative hydrologic assessment: Water Resources Research, v. 27, no. 9, p. 2247-2257.

Fredrickson, L.H., and Taylor, T.S. (1982). Management of seasonally flooded impoundments for wildlife. Resource Publication 148. US Dept. of the Interior, Fish and Wildlife Service, Washington, DC.

Grober, L.F., Karkoski, J., and. Poole, T. (1995). Water quality impact of wetlands on the San Joaquin River, California, paper no.00149 In T.G. Cleveland [ed.], Advances in the development and use of models in water resources:Proceedings of the American Water Resources Association held in Houston, Texas, November 5-10, 1995.

Grober, L.F., Karkoski, J., and Johnston, W.J. (2006). The need and development of TMDLs for the San Joaquin Valley of California (this proceedings).

Karkoski J., Quinn, N.W.T., Grober, L.F. (1995). The potential for real-time water quality management in the San Joaquin River Basin of California. Advances in Model Use and Development for Water Resources. AWRA Annual Conference and Symposium Proceedings, Houston, Texas, July.

Ploss, L.F., and Buck, B.M. (2006). An alternative water quality management plan for the San Joquin River Basin (this proceedings).

Quinn, N.W.T. (1999). A Decision Support System for Real-Time Management of Water Quality in the San Joaquin River, California. $3^{\text {rd }}$ International Symposium on Environmental Software Systems (ISESS'99), August 30September 2, 1999, Dunedin, New Zealand. 
Quinn, N.W.T., Chen, C.W., Grober, L.F., Kipps, J. and Cummings, E. (1997). Computer model improves real-time management of water quality. California Agriculture, Vol. 51, No. 5.

Quinn, N.W.T., and Karkoski, J. (1998). Potential for real time management of water quality in the San Joaquin Basin, California. American Water Resources Association, Vol 34, No. 6.

Quinn, N.W.T. (1995). A compliance monitoring program for use and operation of the Grasslands Bypass for drainage conveyance in the western San Joaquin Valley. Berkeley National Laboratory Topical Report, LBNL-39052, Berkeley, CA 94720.

Quinn, N.W.T., Chen, C.W., Grober, L.F., Kipps, J. and Cummings, E.. (1997). Real-time management of water quality in the San Joaquin River. California Agriculture, Sept/Oct issue.

Quinn, N.W.T., Hanna, W.M., Hanlon, J.S., Burns, J.R., Taylor, C.M., Marciochi, D., Lower, S., Woodruff, V., Wright, D. and Poole, T. (2004). Real-Time Water Quality Management in the Grassland Water District. Berkeley National Laboratory Topical Report No. 56825, Berkeley, CA 94720.

San Joaquin Valley Drainage Program. (1990). A Management Plan for Agricultural Subsurface Drainage and Related Problems on the Westside San Joaquin Valley. U.S. Dept. of Interior and California Resources Agency.

Schoups, G., Hopmans, J., Young, C.A., Vrugt, J.A., Wallender, W.W., Tanji, K.K., and Panday, S. (2005). Sustainability of Irrigated Agriculture in the San Joaquin Valley, California. Proceedings of the National Academy of Sciences 102(43): 15352-15356.

Ward, W.P., Johnston, W.R., and Niemi, M. (2006). The San Joaquin Valley East Side perspective (this proceedings).

Westlands Water District. (1999). Water Management Plan: 1999. September 1999.

Westlands Water District. (2003). Analysis of Economic Impacts of Land Retirement in Westlands Water District, Westlands Water District, Fresno, CA.

West Stanislaus Irrigation District. (1994). Water Conservation Plan. March 1994.

Williams, O.E. (1996). Waterbird responses to late winter and early spring drawdowns of moist-soil managed wetlands in California's San Joaquin Valley. M.S. thesis, Humboldt State University. 136 p. 